«Keruen» scientific journal

M.O.Auezov Institute of Literature and Art

ISSN 2078-8134

Volume 3, Number 68 (2020)

https://doi.org/10.53871/2078-8134.2020.3-05

IRSTI 17.09.91

\author{
A.K.Mashakova ${ }^{1}$, M.M.Khabutdinova ${ }^{2}$ \\ ${ }^{1}$ M.O. Auezov Institute of Literature and Art, Almaty, Kazakshtan, \\ ${ }^{2}$ Kazan Federal University, Kazan, Russia, \\ e-mail: ${ }^{1}$ a_mashakova@mail.ru, ${ }^{2}$ mileuscha@mail.ru \\ ORCID: 0000-0001-5700-457X
}

\title{
PUBLICISM OF KAZAKHSTAN AT THE PRESENT STAGE
}

\begin{abstract}
The article deals with modern publicism of Kazakhstan. The novelty of the research is related to the fact that the authors of the paper have identified the most significant figures among contemporary Tatar publicists. The material for the study include publicist books, feature articles, essays, papers by M. Erzin, G. Khayrullin, R. Bikmukhametova, F. Baygeldinov, T. Karimov, S. Bagautdinov. The study showed that modern Tatar publicism in Kazakhstan is distinguished by dynamic development. The Tatar publicists, on the one hand, turn to the historical past of the Tatar people, on the other - devote their works to the modern life. They highlight not only the life of the Tatars in Kazakhstan, but also relevant issues, the phenomena of the current life of modern society in our country, comprehending aesthetic ideals and moral values.
\end{abstract}

Key words: publicism, Kazakhstan, publicist books, feature articles, essays, papers, Tatar publicists.

Introduction. Modern literary process in Kazakhstan along with Kazakh, Russian, Uighur, German, Korean, Kurdish, Uzbek literature is also represented by Tatar literature. For the first time a study of the Tatar literature of Kazakhstan was conducted in 2004 in the joint monograph «Literature of the Peoples of Kazakhstan» at the M.O. Auezov Institute of Literature and Art. The section «Tatar Literature» (Fatkullin and Tusupova, 2004) acquaints the readers with the development of the Tatar literature of Kazakhstan in the beginning and the middle of the XX century, as well as with Kazakh-Tatar literary relations. In 2014 a joint monograph «Modern Literature of the People of Kazakhstan» was published, which reflects the development of national literatures of the country in the period of independence. One of the authors of the paper prepared a section on modern Tatar literature of Kazakhstan. In the last few years, on this topic were published papers in the following journals: «Tatarica» (Khabutdinova and Mashakova, 2016), «TOJDAC» (Fattahova and Khabutdinova, 2017), «Astra Salvensis» (Nasyrova and Khabutdinov, 2017), «News of NAS RK» (Mashakova and Khabutdinova, 2017). This paper is devoted to the creative writings of contemporary Tatar publicists in Kazakhstan. The relevance of the topic is due to the importance of studying national literatures at the present stage, when Kazakhstan positions itself in the modern world as a State in which many nations live in peace and harmony. The novelty of the study is related to the fact that the authors of the paper identified the most significant figures among contemporary Tatar publicists of Kazakhstan.

Methods. The used methods: problem-thematic, analytical, biographical etc.

Results. Contemporary Tatar publicists Munir Erzin, Grif Khayrullin, Raisa Bikmukhametova, Farid Baigeldinov, Taufik Karimov, Shamil Bagautdinov who create their works in the Tatar and the Russian languages make an important contribution to the development of Kazakhstan publicism. With the purpose of conducting this research, the authors established creative contacts with many of them, received valuable materials, and interviews. Their books «The 
Path of Ancestors», «Secrets of the Centuries», «The History of the Tatars», «The Tatars in the North of Kazakhstan», «We are All Children of the Earth» etc. served as a research material.

Discussion. M. Erzin is a member of the Board of the Tatar-Bashkir Cultural Center, laureate of the award «Crystal Pen», which is awarded to the best journalists of the Republic of Tatarstan. M. Erzin belongs to the Ili Tatars, he was born in the city of Burchum, Altai district of the present Xinjiang Uygur Autonomous Region. The Tatar Diaspora in Kazakhstan, like all diasporas in Central Asia, is multilayered in terms of settlement time as well as original places of residence. Here live the descendants of Kazan, Ufa and Kasimov Tatars, mishars from the former Nizhny Novgorod and Saratov provinces. There is a special layer of Ili Tatars who have been repatriated from Xinjiang Uygur Autonomous Region of China in the 50s of the XX century. All of them form a single diaspora.

In 2005, he published a publicist book «Ancestral Path», dedicated to the history of the Tatars who in the XIX century moved from Russia to Semipalatinsk and Zaisan, in the early XX - to the Altai District of North-Western China, and in the middle of the XX century they returned to Kazakhstan. The book has the autobiographical nature. M. Erzin turns to the past, describes his childhood and youth in China, and how he moved to Kazakhstan. The author describes the life of Xinjiang in the forties and fifties of the XX century and socio-political events in the life of the region, which he has witnessed. He involves materials and sources in the Kazakh, Russian, Tatar, Chinese and Uighur languages, as he is fluent in them. In the Foreword to the book the author wrote: «The Tatars are the people who left their native places at different times due to different reasons, and was dispersed across many lands. Part of this people settled in Kazakhstan and Central Asia and further along its territory in the East Turkestan - in the districts of the present Xinjiang Uygur Autonomous Region. This book mainly narrates about the Tartars of the Burchum district of the Altai district of Xinjiang province» (Erzin, 2005: 5).

The author of the book tells how in the Xinjiang province, the Tatar intellectuals, artisans, traders, farmers contributed significantly to the development of culture, education, trade and agriculture. At the same time, the Tatars managed to preserve their national identity, language, traditions and customs. In the 1930s, the commercial capital and industrial enterprises of the Tatar businesspersons grew at a rapid pace, and their trade relations with Russia and internal provinces of China have expanded. However, Shen Shijai, who became a Governor General of Xinjiangin in 1937 began confiscation of property, suppression of progressively thinking people and entrepreneurs. Trade and production activities of the Tatar business people were on the verge of termination. The socio-economic situation of the population worsened day by day. Since the 1950s, the Tatars began to move to the Soviet Union. Immigrants from the Ili, Tarbagatai, Altai, Urumqi districts have concentrated in Alma-Ata city. «In this blessed place, thanks to the cordiality of the Kazakh people, they were given the opportunity for further development and prosperity» (Erzin, 2005) - wrote M. Erzin.

Having arrived in Kazakhstan, M. Erzin, who had worked as a journalist in the editorial office of the newspaper «Revolutionary Eastern Turkestan», got a job of a literary employee in Almaty at the editorial office of the Uighur newspaper «Banner of Communism». Then, for many years he worked as a senior researcher at the Institute of Oriental Studies of the National Academy of Sciences of the Republic of Kazakhstan.

By his articles M. Erzin significantly enriches the knowledge on the Tatars in Kazakhstan. $\mathrm{He}$ is the author of the book «Secrets of the Centuries» (Erzin, 2012), positive reviews of which were published in the newspaper «Fiker-Omet». Professor G. Khairullin outlined the value of the book for the development of modern Tatar studies. Researcher on Turkic studies A. Kamalov pays attention to the fact that the author used Chinese sources to restore the main stages of the early history of the Tatars.

The book «Secrets of the Centuries» includes the articles by M. Erzin in the Tatar and Kazakh languages. The article «Glorious Pages» is devoted to the newspaper «Hope», published in Kazakhstan in the Tatar language (one of the founders of the newspaper was M. Erzin). In honor of the 140th anniversary of the Zaisan city in the East Kazakhstan region, the article «The tracks will 
not disappear» was written. In the articles «Monuments of antiquity» and «Ancient Almalyk», the author wrote about historical monuments found in the Ili-Kazakh autonomous region of the XUAR. The article «Welcome "the Neighbor"» is devoted to the publication of the journal «The Neighbor» in Kazakhstan. The article «The journalist's destiny» tells about the Tatar poet and journalist H. Tukhfi - employee of the newspaper «Revolutionary East Turkistan», with whom M. Erzin was personally acquainted. The articles «Unique taste of Tatar meals», «Uighurs of Altai» are very interesting. In total, 44 articles of the author are included into the book. The inseparable property of the publications of M. Erzin is the combination of a wide scope of the phenomena of cultural life of the Kazakh, Tatar, Uigur peoples with penetration into the essence of the depicted phenomena.

G. Khayrullin is the author of the publicist books «The History of the Tatars» (1998), «The Tatars: Pages of History and Today» (1998, co-authored by A. Khamidullin), «The Traditional Culture of the Tatar People» (2000), «Essays on History and Culture of the Bashkir people» (2004). In 2011 the encyclopedic dictionary «The Tatars in Kazakhstan» edited by G. Khairullin was published in Almaty. G. Khayrullin was the editor-in-chief of the newspaper «Fiker» and the President of the Association of the Tatars and the Bashkirs in Kazakhstan.

The book «History of the Tatars», which describes the history of one of the largest groups of the Turkic peoples, who are called «The Volga Tatars» is especially popular among the readers. The publication of the manuscript of the book on the Internet, in particular, in «The Tatar electronic library», in the «Books» section of the site «Tatar jaunarleri», as well as on the site of the Tatar Historical Society is the evidence of this fact. In addition, the book was supplemented and republished in 2010 in Almaty, and in 2012 it was published in Saarbrucken (Germany). As indicated in the annotation to the book, «based on the analysis of the known studies, the historical path of the Tatar people from ancient times to nowadays has been observed. State formations have been explored, in which establishment and development the ancestors of the modern Tatars have actively participated» (Khayrullin, 1998: 2). The book consists of the sections «The Far Ancestors of the Tatars», «Great Bulgaria in the Volga Area», «The Golden Horde Period», «The Kazan Khanate», «The Bulgar Tatars in the Empire», "The Soviet Period of the Tatars' Life», «History and Modernity». The author of the book «History of the Tatars» made a conclusion, that the first major migration wave of the Tatars from the Volga region to the Urals, Siberia, Kazakhstan and Central Asia, began immediately after the tragedy of 1552. He wrote: «Often the Tatars left for Kazakh lands, because they were unable to withstand the tax burden or avoiding soldatchina ... Mostly the local population were kind to the Tatars, provided shelter and showed steppe hospitality. In turn, the Tatars brought here their culture of the sedentary life, commitment to Islam and a high level of literacy» (Khayrullin, 1998: 53).

G. Khairullin's book «The Tatars: Pages of History and Today» is included into the series «Kazakhstan is our common home». It briefly covers the history of the Tatars and describes in detail the life of the Tatars in Kazakhstan in recent years.

G. Khairullin's book «Traditional culture of the Tatar people», published with the financial support of the Almaty Cultural Foundation of the Turkic peoples, is dedicated to those people who developed and preserved the distinctive culture of the Tatar people in Kazakhstan. The author is convinced that «The respect for the history and culture of the own and any other nation is the main condition for ensuring peaceful cooperation of the citizens in any State» (Khayrullin, 2000: 118).

The member of the Union of Journalists of Kazakhstan R. Bikmukhametova is the author of the books «Let's Worship Those Great Years!» (2010), «The Chronicle of the Independence» (2011), «We Are All the Children of the Earth» (2013), essays and reports published in the periodicals in Kazakhstan, Russia and the USA. She worked in the newspaper «Leninskoye Znamya», on the regional television in Petropavlovsk. She produced interesting documentary films «Countrymen», «Let's worship those great years». Being the reporter of the international newspaper «Ves Mir» (is published in Kazakhstan), R. Bikmukhametova was reporting from San Francisco, where the Tatars arrived from different countries to celebrate the 50th anniversary of the Tatar Diaspora. R. Bikmukhametova is a member of the Assembly of the Peoples of Kazakhstan, Chairperson of the North-Kazakhstan Tatar-Bashkir Center «Duslyk», Honorary Citizen of the 
North-Kazakhstan region, Honored figure of Culture of the Republic of Tatarstan, delegate to the World Congress of the Tatars.

In 2004 the book «The Tatars in the Northern Kazakhstan» was published in the publishing house «Northern Kazakhstan» which was edited by R. Bikmukhametova. It includes articles published in the 1990-2000's which are dedicated to the history and the present of the Tatar population of the region. The book consists of four parts. The first part «From the depths of the centuries» presents the articles on the history of the Tatars from ancient times to the present day, the history of the Tatars of Petropavlovsk, cities and villages of the North-Kazakhstan region. R. Davletkildeeva, R. Tyncharova, R. Bikmukhametova wrote articles on famous Tatar families in Petropavlovsk, and about mosques. The historical essay on Mamlutka city was presented by R. Nurmukhamedova and A. Sivinskaya. H. Shagvaleyeva, a member of the Journalists' Union of Kazakhstan, the editor of the regional newspaper "Znamya Truda», dedicated the publication to the Mamlyutovs family - to the descendants of Mavlyut Valguzin, whose name was given to the city. At the end of the XVIII century, he arrived to these area and laid the foundation for the future Tatar settlement. By the end of the XIX century, Mamlutka was a settlement, and in the middle of the XX century it received the status of a city. The second part «History in Faces» is dedicated to the famous Tatars of Petropavlovsk, who lived in the city during different periods. Among them V. Yangurazov, A. Yagufarov, R. Ryazapov, K. Sutyushev, A. Adnashev, M. Khusainov, R. Davletkildeyeva, A. Shafeyeva, G. Bichurina. The article on Z. Zhaltyrova - the wife of the Kazakh poet M. Zhumabayev is interesting. The third part of the book «On the pages of periodicals» includes articles on holding of national holidays in the North-Kazakhstan region during the 1990s. Particularly during these years the celebration of Nauryz and Sabantuy has revived, the TatarBashkir club «Duslyk» has been established, which later has become a regional ethno-cultural center.

The book «We are all the children of the Earth» begins with an essay «My Dear Person» which is about R. Bikmukhametova's father $-\mathrm{G}$. Mamlyutov, a participant of the Great Patriotic War, a native of the village Mamlyutka. The author tells about the war and post-war years: «We, the children of the postwar period, remember the victorious fanfare, and the black cardboard radio plates that played bravura marches, as well as the sad faces of neighbors and relatives whose fathers and sons died at the front. They believed and continued to wait for them» (Bikmukhametova, 2013: 12). The life of G. Mamlyutov was not easy, in the age of forty he became a widower, but, despite the difficulties, he brought up five children. R. Bikmukhametova speaks respectfully of her second mother Maria Sergeyevna, with whom the children «did not feel themselves the orphans». The daughter remembers the father as a kind, decent person who had a beautiful soul.

The essay «Origins» is dedicated to the Cossack village Stanovoye, where R. Bikmukhametova's mother B. Aitova grew up. The author writes about the formation and prerevolutionary life of the village, touches on the theme of forced collectivization, dekulakization, and repressions against the Cossacks. In 2002, the 250th anniversary of the village Stanovoye was celebrated. The representatives of the famous dynasties, who have glorified this land in different years, have arrived to the celebration. R. Bikmukhametova - the granddaughter of the hereditary Cossack Sibagatulla Aitov was among the speakers at the ceremonial part.

In the detailed and informative essay «The Tatars of Northern Kazakhstan» the author pays special attention to the modern period, the holding of the Sabantuy, the establishment of the TatarBashkir Center «Duslyk», the ties with the historical homeland, trips to Kazan, the friendship between the representatives of different nationalities of Northern Kazakhstan, who are gathering at the festivals, competitions, exhibitions and folklore concerts. The essay concludes with the following words: «About 15 thousand Tatars and Bashkir people live today in the north of Kazakhstan. The opportunity to learn the native language, listen to live speech and music, hold celebrations, communicate with business and creative communities of Tatarstan, educate children on grants, participate in the work of the Assembly of the Peoples of Kazakhstan ... gives hope for the preservation of peace and harmony in our common house - the Republic of Kazakhstan» (Bikmukhametova, 2013: 36). 
The book «The Tatars in the North of Kazakhstan» has received a positive evaluation of $\mathrm{Z}$. Makhmutov in the magazine "Gasyrlar avazy», who is close to this subject as he is the author of the scientific monograph "The Tatars of the North Kazakhstan region: history, culture, identity» (2011), which was written as a result of the field research on the Tatars in 2005-2010. He defended his thesis «Ethnic processes in the environment of the modern Tatar population in the North Kazakhstan region of the Republic of Kazakhstan». Z. Makhmutov is a participant and coordinator of the research projects «The Tatar population of the Northern Kazakhstan», «The Tatar population of Kazakhstan». He actively makes presentations and scientific reports at conferences in Russia and Kazakhstan, and publishes articles. The relevance of his research is due to the fact that after gaining independence of Kazakhstan, the Tatars in the republic received the status of Diaspora. The study of such ethnic groups, who are dispersedly living outside the historical homeland, is one of the priorities of current ethnography. Fifty percent of the total population of the Tatars of the region live in Petropavlovsk. In Mamlyutka and Stanovoye they live compactly, and they live dispersedly in all other settlements.

Biographical essay «Long echo of the cold war» by F. Baygeldinov is devoted to the Great Patriotic War. His childhood took place in terrible military years, and adolescence - in the hard post-war period. In the essay «The Long Echo of the Cold War» F. Baygeldinov talks about his uncle Zaisan Zamanovich Ayupov, who went to the front when he was twenty years old, and returned in 1947 with military awards. The real pictures of the war and post-war life are described in a sensual way: «And I realized that all of us who lived at that time, irrespective of age, place of stay and degree of participation, are all irradiated, concussed, deformed and united by one common and immense disaster, and therefore now we are all not only witnesses, in whose hearts the silent echo of its bell still echoes, but all of us, of course, are part of that war» (Baygeldinov, 2008: 54).

Travel essays by F. Baygeldinov «Italian sketches» give the opportunity to enjoy art in the best galleries in Italy, immerse into the world of Michelangelo and Raphael in the treasuries of the Vatican, and spend the night on the Palatine and swim in a gondola through the canals of Venice. In the book, along with the author's delicate observations, there are many lyrical and philosophical reflections on the past, present and future on the background of modernity, and it is full of love for the native land, which is especially keenly felt when you are far from it. G. Belger believes that F. Baygeldinov «undertook his European journey and was fully armed with knowledge, and was historically, aesthetically, morally prepared for the perception of all layers of ancient and modern culture, was able to transmit everything what he has seen by alive, exalted, excited, elegant Russian syllable as well as keenly and sensibly, extremely sincerely reflecting on the relevant issues of our life» (Baygeldinov, 2006: 4).

The essays by T. Karimov highlight the important events in the life of our country («Olympic Games and Kazakhstan»), the history of the native city («Mikhail Guryev», «Patrons Akhmirovs»), famous people of Atyrau («Admiral Vladimirsky»). T. Karimov is a member of the Union of Writers of Kazakhstan and the Union of Writers of Tatarstan, the author of the books «... And All the Colors of the Rainbow» (2000), «Where Are You, My Homeland, My Pain and Light?» (2003), «Katharsis» (2003); «The clouds are floating ...» (2004), «Armysyn, menin zhanujam» (2005, «Hello, my home»), «Toslar balkyshy» (2009). The book «Where are you, my Homeland, My Pain and Light?» is included into the 100-volume Library of Kazakh poets and writers «Kazyna». He is an Honorary Professor of Atyrau University (Kazakhstan), Honorary Citizen of Tucson (USA). T. Karimov is actively engaged in public activities in the Republic; he was twice elected the President of the Association of Tatar and Bashkir ethno-cultural centers of the Republic of Kazakhstan in 2007 and 2010, and later he was the Honorary President of the Association of Tatars and Bashkirs of Kazakhstan. In 2017 T. Karimov was elected Chairman of the Congress of Tatars and Bashkirs of Kazakhstan. He is also a member of the Executive Committee of the World Congress of Tatars. According to T. Karimov, «the Tatars and Bashkirs who are close to the Kazakh people due to the related language, a single religion and destiny-represent a positive force in strengthening the unity of the Kazakhstan people» (Karimov, 2009). 
Sh. Baigutdinov dedicates his articles to the history of the Eastern Kazakhstan. The newspapers «Luch», «Sem Dney», «Vesti Semeyya», «Rudnyi Altai» published his articles «The war didn't passed by the Sennovsky side», «Altai masons», «Honey fields of Belovodje», landscape sketches «The Mystery of the Glyaden Mountain», «Annals of a unique nature», portrait essay «The name of the director N.I. Shaporev has been immortalized» etc. He has a wide range of interests. In the article "Originated from Nugumanovo» the author tells about the fate of the members of the Tatar family of Valievs from Katon-Karagay, who were repressed. He wrote the article «One hundred matches to the century» about the events dedicated to the 100th anniversary of Kazakhstan football. A lot of publications reflect the daily life of the native land. The article «The 30-year-old Zoryushka» tell about the Russian folklore group «Zoryushka» from the village of Novopolyakovka in Katon-Karagai district. The magazine «Prostor» published his documentarypublicist story «The Mysterious and Unknown Area», dedicated to the residents of Bukhtarma Valley villages.

Conclusion. Publicism in Kazakhstan is interesting in terms of the topics, issues, genre specifics. «Publicism actively influences on the development of the spiritual and material components of culture, transforming them into the direction of the vector of public sentiments» (Pautov, 2012: 3). Modern Tatar publicism in Kazakhstan is distinguished by dynamic development. Tatar publicists, on the one hand, turn to the historical past of the Tatar people, on the other - devote their works to modern life. They cover not only the life of the Tatars in Kazakhstan, but also relevant issues, the phenomena of the current life of modern society in our country, comprehending aesthetic ideals and moral values. Publications of Tatar authors testify that the Tatar Diaspora - is an integral part of the Kazakhstan society.

\author{
Машақова А.Қ. ${ }^{1}$, Хабутдинова М.М.² \\ ${ }^{1}$ М.О.Әуезов ат. Әдебиет және өнер институты, Алматы қ., Қазақстан, \\ ${ }^{2}$ Казань федеральді университеті, Казань қ., Ресей, \\ e-mail: ${ }^{1}$ a_mashakova@mail.ru, ${ }^{2}$ mileuscha@mail.ru
}

\title{
ҚАЗІРГІ КЕЗЕНДЕГІ ҚАЗАҚСТАН ПУБЛИЦИСТИКАСЫ
}

Аңдатпа. Мақала Қазақстандағы қазіргі публицистикасына арналған. Зерттеудің жаңалығы осы мақала авторларының қазіргі татар публицистерінің арасындағы ең маңызды тұлғаларын айқындаумен байланысты болып табылады. М. Ерзин, Г. Хайруллин, Р.

Бикмухаметова, Ф. Байгельдинов, Т. Каримов, Ш. Багаутдиновтың публицистикалық кітаптары, очерктері, эсселері мен мақалалары зерттеу материалдары ретінде қарастырылды.

Зерттеу Қазақстандағы қазіргі татар публицистикасының динамикалық дамуы мен ерекшелігін көрсетеді. Татар публицистері, бір жағынан, татар халқының тарихи өткеніне жүгінсе, екінші жағынан, олар өз шығармаларын қазіргі заманғы өмірге де арнайды. Олар қазақстандық татарлардың өмірін ғана суреттеп қоймай, сонымен бірге, біздің еліміздегі эстетикалық идеалдар мен моральдық құндылықтарды көрсететін қазіргі қоғамда болып жатқан құбылыстар мен өзекті мәселелерді қамтиды.

Кілт сөздер: публицистика, Қазақстан, публицистикалық кітаптар, очерктер, эсселер, мақалалар, татар публицистері.

Машакова А.К ${ }^{1}$, Хабутдинова М.М. ${ }^{2}$

${ }^{1}$ Институт литературы и искусства им. М.О.Ауэзова, г. Алматы, Казахстан,

${ }^{2}$ Казанский федеральный университет, г. Казань, Россия, e-mail: ${ }^{1}$ a_mashakova@mail.ru, ${ }^{2}$ mileuscha@mail.ru 
Аннотация. Статья посвящена современной публицистике в Казахстане. Новизна исследования связана с тем, что авторами статьи выявлены наиболее значимые фигуры среди современных татарских публицистов. Материалом для исследования послужили публицистические книги, очерки, эссе, статьи М. Ерзина, Г. Хайруллина, Р. Бикмухаметовой, Ф. Байгельдинова, Т. Каримова, Ш. Багаутдинова. Исследование показало, что современную татарскую публицистику в Казахстане отличает динамичное развитие. Татарские публицисты, с одной стороны, обращаются к историческому прошлому татарского народа, с другой - посвящают свои произведения современной жизни. Они освещают не только жизнь казахстанских татар, но и актуальные проблемы, явления текущей жизни современного общества в нашей стране, осмысливая эстетические идеалы и нравственные ценности.

Ключевые слова: публицистика, Казахстан, публицистические книги, очерки, эссе, статьи, татарские публицисты.

Information about authors:

A.K.Mashakova, .O. Auezov Institute of Literature and Art, Almaty, Kazakshtan, ORCID iD: 0000-0001-5700457X. Scopus iD: 57196947633. WoS iD: Y-5258-2019

M.M.Khabutdinova, Kazan Federal University, Kazan, Russia, mileuscha@mail.ru

\section{REFERENCES}

[1] Baygeldinov F. (2006). Italian sketches. Almaty: Interligal. (rus.).

[2] Baygeldinov F. (2008). Provincial history. Almaty: Interligal, (rus.).

[3] Bikmuhametova R. (2013). All of us are children of the earth. Petropavlovsk: Severnyi Kazahstan. (rus.).

[4] Erzin M. (2005). Track of ancestors. Almaty (rus.).

[5] Erzin M. (2012). Secrets of the Centuries. Almaty (tat.).

[6] Fatkullin F., Tusupova A. (2004). Tatar Literature. Literature of the Peoples of Kazakhstan (272-294). Almaty: Gylym (rus.).

[7] Fattahova L., Khabutdinova M. (2017). Tatar-Kazakh cultural and literary connections at the beginning of the XXI century. TOJDAC: The Turkish Online Journal of Design, Art and Communication (Web of Science). 7: 859-865 (eng.).

[8] Karimov T. (2009). The Assembly has reached a new stage in its development. Metakz. Retrieved 15.02.2018. from http://meta.kz//88333-taufik-karimov.html (rus.).

[9] Khabutdinova M.M., Mashakova A.K. (2016). On the self-identity of Kazakhstan Tatars (based on the lyrics of modern Tatar poets). Tatarica (Russian Science Citation Index). 1: 59-64 (eng.).

[10] Khayrullin G.T. (1998). History of Tatars. Almaty: Kazintegraf. (rus.).

[11] Khayrullin G.T. (2000). Traditional culture of the Tatar people. Almaty: Kanagat (rus.).

[12] Mashakova A., Khabutdinova M. (2017). On the Ethnic Self-Identity of Kazakhstan Tatars. News of NAS RK. 2: 222-226 (rus.).

[13] Nasyrova A., Khabutdinov A. (2017). The role of prayer discourse for Karaganda concentration camp image creation in the works of Tatar writer Ayaz Gilyazov and the Kazakh poet Halim Zhaylybay. Astra Salvensis (Scopus). 5(10): $201-207$ (eng.).

[14] Pautov A.D. (2012). History of Russian publicism. Omsk: Izd-vo SibGUFK (rus.).

\section{ӘДЕБИЕТ}

[1] Байгельдинов Ф. Итальяндық құрылым. - Алматы: Интерлигал, 2006 (орыс.).

[2] Байгельдинов Ф. Провинциялық әңгімелер. - Алматы: Интерлигал, 2008 (орыс.).

[3] Бикмухаметова Р. Біз бәріміз жердің балаларымыз. - Петропавловск: Северный Казахстан, 2013 (орыс.).

[4] Ерзін М. Бабалар ізімен. - Алматы, 2005 (орыс.).

[5] Ерзін М. Ғасырлар сере. - Алматы, 2012 (тат.).

[6] Қарімов Т. Ассамблея өз дамуының жаңа кезеңіне аяқ басты. Metakz. Қаралған күні: 15.02.2018. http://meta.kz//88333taufik-karimov.html (орыс.).

[7] Машақова А., Хабутдинова М. Қазақстан татарларының этникалық сәйкестенуі туралы. // ҚР ҰҒА Хабарлары. - 2017. 2. - 222-226 б. (орыс.).

[8] Насырова А., Хабутдинов А. Намаз дискурсының татар жазушысы Аяз Гилязов пен қазақ ақыны Ғалым Жайлыбайдың шығармаларындағы Қарлаг бейнесін ашудағы рөлі. // Astra Salvensis (Scopus). - 2017. - 5 (10). - 201-207 б. (ағыл.).

[9] Паутов А.Д. Ресей публицистикасының тарихы. - Омбы: СибГУФК баспа уйі, 2012 (орыс.).

[10] Фаткуллин Ф., Түсіпова А. Татар әдебиеті. Қазақстан халықтарының әдебиеті (272-294). - Алматы: Ғылым, 2004 (орыс.).

[11] Фаттахова Л., Хабутдинова M. XXI ғасыр басындағы татар-қазақ мәдени және әдеби байланыстары. TOJDAC: The Turkish Online Journal of Design, // Art and Communication (Web of Science). - 2017. - 7. - 859-865 б.(ағыл.).

[12] Хабутдинова М.М., Машақова А.К. Қазақстан татарларының этникалық сәйкестенуі туралы (қазіргі татар ақындарының поэзиясы мысалында). // Татарика (РИНЦ). - 2016. - 1. - 59-64 б. (ағыл.)

[13] Хайруллин Г.Т. Татарлар тарихы. - Алматы: Казинтеграф, 1998 (орыс.).

[14] Хайруллин Г.Т. Татар халқының дәстүрлі мәдениеті. - Алматы: Қанағат, 2000 (орыс.).

\section{ЛИТЕРАТУРА}

[1] Байгельдинов Ф. Италийские наброски. - Алматы: Интерлигал, 2006 (рус.). 
[2] Байгельдинов Ф. Провинциальные истории.- Алматы: Интерлигал, 2008 (рус.).

[3] Бикмухаметова Р. Все мы - дети земли. - Петропавловск: Северный Казахстан, 2013 (рус.).

[4] Ерзин М. Тропою предков. - Алматы, 2005 (рус.).

[5] Ерзин М. Тайны веков. - Алматы, 2012 (тат.).

[6] Каримов Т. Ассамблея вышла на новый этап своего развития. Metakz. Дата обращения: 15.02.2018. http://meta.kz//88333taufik-karimov.html (рус.).

[7] Машакова А., Хабутдинова М. Об этнической самоидентификации татар Казахстана. // Известия НАН РК. - 2017. - 2. C. 222-226 (pyc.).

[8] Насырова А., Хабутдинов А. Роль молитвенного дискурса в раскрытии образа Карлага в произведениях татарского писателя Аяза Гилязова и казахского поэта Галыма Жайлыбая. // Astra Salvensis (Scopus). - 2017. - 5 (10) - C. 201-207 (англ.).

[9] Паутов А.Д. История публицистики России. - Омск: Изд-во СибГУФК, 2012 (рус.).

[10] Фаткуллин Ф., Тусупова А. Татарская литература. Литература народов Казахстан (272-294). - Алматы: Гылым, 2004. C. 272-294 (рyc.).

[11] Фаттахова Л., Хабутдинова М. Татарско-казахские культурные и литературные связи в начале XXI века. - TOJDAC: The Turkish Online Journal of Design, Art and Communication (Web of Science). - 2017. - 7. - С. 859-865 (англ.).

[12] Хабутдинова М.М., Машакова А.К. Об этнической самоидентификации татар Казахстана (на примере поэзии современных татарских поэтов). // Татарика (РИНЦ). - 2016. - 1. - С. 59-64 (англ.).

[13] Хайруллин Г.Т. История татар. - Алматы: Казинтеграф, 1998 (рус.).

[14] Хайруллин Г.Т. Традиционная культура татарского народа. - Алматы: Канагат, 2000 (рус.). 